International Journal
of
UNIVERSITY OF MURCIA

\title{
Shakespeare and Mercy at the Vatican, 2016
}

\author{
MARTA CEREZO MORENO* \\ UNED (Spain)
}

Received: 28/02/2020. Accepted: 15/09/2020.

\begin{abstract}
This article explores a central chapter in the history of the Catholic reception of Shakespeare's work during the contemporary age: the Catholic readings in 2016 of Shakespeare's dramatic presentation of mercy in the context of the celebrations of the $400^{\text {th }}$ anniversary of Shakespeare's death and the Holy Year of Mercy. This study directs its focus first to Catholic public manifestations on mercy -such as printed volumes, articles and cycles of lectures- which incorporated Shakespeare's reflections on mercy within their religious debate. Second, it studies how the Globe to Globe Hamlet performance at the Holy See on 13 April 2016 triggered the interpretation within the Vatican context of Hamlet as a play which, despite its focus on revenge and crime, opens up glimpses of mercy that allow a redefinition of justice.
\end{abstract}

KEYWORDS: Shakespeare, Catholicism, Vatican, Mercy, Hamlet, 2016.

\section{INTRODUCTION}

In the afterword to the Cambridge Companion to Shakespeare and Religion (2019), the former Archbishop of Canterbury Rowan Williams beautifully presents Shakespeare's plays as a religious dialogue with each other in which the following questions are central: solidarity and compassion; prayer and guilt; power and gratuity. As Williams

\footnotetext{
*Address for correspondence: Marta Cerezo Moreno, Departamento de Filologías Extranjeras y sus Linguiísticas, Facultad de Filología, UNED, Madrid, Spain; e-mail: mcerezo@flog.uned.es
}

(C) Servicio de Publicaciones. Universidad de Murcia. All rights reserved.

Print ISSN: 1578-7044; Online ISSN: 1989-6131
IJES, vol. 20 (3), 2020, pp. 145-164 doi: $10.6018 / \mathrm{ijes} .416521$ 
notes, they are religious themes as they are intrinsic to human interaction and selfknowledge and "in the sense that they are where the language of grace and communion comes in, whatever ontological implications we want to give this" (285). This article focuses on the unexplored conversation established in 2016 between Shakespeare, the Holy See and other various Catholic discourses on mercy on both the $400^{\text {th }}$ anniversary of Shakespeare's death and the Holy Year of Mercy. The contemporaneity of the author's plays was found in their reflection on all the issues in dialogue mentioned by Williams, which were central in the fundamentals of the Jubilee summed up in its motto: Merciful like the Father (Pope Francis, 2015, April 11: para. 14). That God's mercy was infinite and that the compassionate recognition of the other must guide human lives were the principal messages of the Pope and the Vatican in 2016. The 2016 Catholic discourses interpreted Shakespeare as a theatrical spiritual force that builds bridges between people and that evokes an ecumenical sense of reconciliation and forgiveness through plays like The Merchant of Venice or Measure for Measure, which unambiguously present mercy as one of their central themes, but also like Hamlet, a play of crime and retribution in which, as this article analyses, representatives of the Vatican, Catholic-oriented literary critics and even diplomatic figures closely associated with the Holy See perceived elements that encourage reflections on mercy.

This study engages with the "turn to religion" (Jackson \& Marotti, 2004, 2011) that has taken place over the last few decades in Shakespeare studies. A landmark in this renewed interest in the playwright's intersection with religious matters was the 2000 meeting of the Shakespeare Institute at Stratford-upon-Avon resulting in the invaluable Shakespeare Survey 54 volume, Shakespeare and Religions (Holland, 2001). Contemporary critical studies on Shakespeare and religion since then have been crossdisciplinary; they mostly combine historicist perspectives with literary analysis and postmodern critical methods, and centre on issues of a wide-ranging, and quite often controversial, nature. Focus has been placed on Shakespeare's religious confession (Asquith, 2005; Holderness, 2016; Mayer, 2006; Milward, 2005; Wilson, 2004), the playwright's use of biblical allusion (Hamlin, 2013, 2019b; Marx, 2000), his work's representation of political theology (Lupton, 2005; Shuger, 2001), textual engagement with his religious context, dramatic portrayal of the Reformation social and theological conflicts and of varied, and also contradictory, early modern religious practices (Loewenstein \& Witmore, 2015; Shell, 2010; Taylor \& Beauregard, 2003). Other scholars have addressed Shakespeare's religious afterlives and have emphasised the way religion has been articulated in Shakespearean performances throughout history (Baker, 2007: 96126), or how the author has been edited, censored or translated considering religious diversity (Wong, 2018). 
This article participates in this current critical debate on the intersection between Shakespeare and religion from a different perspective by stressing a mostly neglected issue: the Catholic Church's reception of Shakespeare during the twentieth and twentyfirst centuries. The relevance of that reception has been primarily noted in a study devoted to the ecumenical and diplomatic implications of the first Shakespeare performance at the Vatican on 12 November 1964 during the celebrations of the $400^{\text {th }}$ anniversary of Shakespeare's birth and third phase of the Second Vatican Council (Cerezo, 2015). This study analyses the second and last occasion Shakespeare was taken to the Vatican -also during a commemorative event and in another crucial context for the Catholic Church such as the Holy Year of Mercy- and it is necessary to contribute to the reconstruction of the contemporary history of the Catholic reception of the playwright's work.

Hannibal Hamlin has recently averred that the "turn to religion" in Shakespeare studies runs parallel to a global religious reorientation provoked by the current international and national conflicts resulting from political and ethnic clashes in which religious difference plays an important role (2019a: xi). In line with Hamlin's perception, the force that emanates from Shakespeare's reflections on mercy has favoured their appropriation by the Catholic Church as inspiration to build a religious discourse of reunion in a fragmented world in need of compassion. In Misericordiae Vultus, the Bull of Indiction of the Jubilee of Mercy given in Rome at Saint Peter's on 11 April 2015, Pope Francis described mercy as "the very foundation of the Church's life" (para. 10) and urged the world not to forget "the great teaching offered by Saint John Paul II in his second Encyclical, Dives in Misericordia" (para. 11). On 30 May 1982 it was precisely John Paul II who exalted The Merchant of Venice as a text on mercy during his apostolic journey to Great Britain. During the Holy Mass of Pentecost in Coventry he asked his audience to pray for the Special Session of the United Nations on Disarmament to be held from 7 June to 10 July and portrayed a world "disfigured by war and violence" which, however, was "long[ing] for justice, yes, but for justice filled with mercy" (para. 2). Portia's lines on mercy and justice were used by the Pope to illustrate the need not just of justice but of human compassion to reach rapprochement: "Being so close as we are to Shakespeare's birthplace we would do well to consider this: 'that in the course of justice none of us should see salvation. We do pray for mercy and that same prayer doth teach all of us to render the deeds of mercy."' (para. 2). Shakespeare was being religiously instrumentalised in the attempt to reach the resolution of social conflicts. John Paul II expressed a desire for a world ruled by "mutual respect and confidence between peoples and nations" achieved through "collaboration and binding agreements" (para. 2). Thirty-four years later, on 24 January 2016, Pope Francis's message for the $50^{\text {th }}$ World Communications Day called 
"Communication and Mercy: A Fruitful Encounter" evokes John Paul II's words and reference to Portia's presentation of mercy when he emphasised communication as necessary to "build bridges between individuals and within families, social groups and peoples" to express "God's compassion, tenderness and forgiveness for all". "Mercy", stated the Pope, "is able to create a new kind of speech and dialogue". "Shakespeare", continued the Pope, "put it eloquently when he said: 'The quality of mercy is not strained. It droppeth as the gentle rain from heaven upon the place beneath. It is twice blessed: it blesseth him that gives and him that takes' (The Merchant of Venice, Act IV, Scene I)". The first part of this article describes various Catholic discourses about mercy -manifested in printed volumes, articles and cycles of lectures- which, like the Pope, turned to Shakespeare to illustrate the Christian sense of forgiveness, justice and compassion during the Holy Year of Mercy.

The second part of this analysis focuses on how the Vatican's interest in Shakespeare's presentation of mercy in 2016 is primarily illustrated by the reception of the Globe to Globe Hamlet performance within the Holy See context. Despite being a play of retaliation, spaces where mercy was also at work were perceived in the text. On 13 April 2016, the Globe to Globe world tour production of Hamlet, after having travelled to 190 countries, was performed in the Apostolic Tribunal the Palazzo della Cancelleria as part of the commemorative events of the $400^{\text {th }}$ anniversary of Shakespeare's death. The performance was arranged by the British Embassy to the Holy See, with the cooperation of the Pontifical Council for Culture, the Administration of the Patrimony of the Apostolic See, the British Council Italy and the staff and management of the Palazzo della Cancelleria. As Bishop Paul Tighe -Adjunct Secretary of the Pontifical Council for Culture at the time and current Secretary- explains, Shakespeare's Globe "approached the Holy See about the possibility of finding a venue, and the possibility of putting on Hamlet. There was immediately a very warm response here to the initiative" (2016: 2:55). Cardinal Gianfranco Ravasi, President of the Pontifical Council for Culture, and Nigel Baker, British ambassador at the time, made the commemorative celebration possible. The private performance was seen by a "select audience of around 170 curial officials, lay Vatican employees and seminarians" (Lamb, 2016). The responses to the staging varied. The information drawn from private conversations with some members of the audience paints the picture of a performance with poor acoustics and that was playing for an audience which, maybe due to the language barrier, was not fully engaged with its spiritual nuances. Other members of the audience, however, have publicly attested to the religious undertones of the performance, enhanced by "the transcendent environment of the Palazzo della Cancelleria", and describe it as "wonderful", "unforgettable", "extraordinary", "unique", "engaging, innovative, entertaining and thought-provoking" (Baker, 2016, April 14). This paper does not intend to give a detailed account of the performance but to focus on the spiritual resonances that the visit of the Globe to Globe to the Vatican had from a (C) Servicio de Publicaciones. Universidad de Murcia. All rights reserved. IJES, vol. 20(3), 2020, pp. 145-164 Print ISSN: 1578-7044; Online ISSN: 1989-6131 
Catholic perspective. Baker underlined the modernity and universality of the play, whose relevance to the Holy See was "made palpable by seeing Hamlet performed right here": "A week after the publication of the Pope's Apostolic Letter on the Family, in front of our eyes was a play about family love, relationships, disagreement and disintegration" (2016, April 14). A correspondence between Pope Francis and Hamlet was also established as the Pope was described in 2016 as someone having, as the Prince of Denmark, "a sea of troubles" (Hamlet 3.1.61) before him in his attempt to reform the Church (Lamb, 2016). ${ }^{1}$ But beyond these connections between the staging of the play and Pope Francis's figure and apostolic message, the Globe to Globe performance of Hamlet in the Vatican was primarily, and interestingly, welcomed, as this article explains, as an appropriate event within the very particular context of the Holy Year of Mercy.

\section{SHAKESPEARE AND THE HOLY YEAR OF MERCY (2016)}

In 2016 the Catholic Church gave clear signs of its interest in Shakespeare's dramatisation of mercy. The Pontifical Council for Culture's journal Culture e Fede 24 focused on Literature and Mercy and included Robin Kirkpatrick's article "Shakespeare in the Light of Cardinal Kasper's Mercy". Richard Rouse defined the volume as "a small celebration of the descriptive power of literature to open our eyes to the human condition" (2016:5). This same idea was behind the cycle of lectures at Pontificia Universitá Gregoriana called "Bibbia, letteratura e teologia" celebrating the $750^{\text {th }}$ anniversary of Dante's birth and the $400^{\text {th }}$ of Shakespeare's death. On 11 and 18 April, Piero Boitani gave two of these lectures on "Il vangelo della misericordia di Shakespeare" in which he analysed the role of mercy in Measure for Measure, The Merchant of Venice and The Tempest. ${ }^{2}$ Asked about the spirit behind this event, Giuseppe Bonfrate, one of its organisers, stated that literary analysis can be an essential way to ascertain the meaning of evangelical scenes and to recognise the seminal power of words, the revelation of human nature and God's presence (Pegoraro, 2016: 25). In the same vein, in the introduction to Culture e Fede 24 Rouse highlighted the power of literature to "take us beyond human justice as depicted in Measure for Measure, into the real source of mercy" and to offer "a glimpse into the divine" (2016: 5). The volume portrayed Shakespeare as the ultimate example of how literature addresses elemental issues of human existence: "In the spirit of the Jubilee Year of Mercy, each time we approach or return to a work of literature, we are faced with the sometimes utopian use of imagination to challenge our ideals and visions, our beliefs and understandings, our relations with our fellow men and women, our priorities, our 
mentality, our culture. As the Bard of Avon put it: 'we are such stuff as dreams are made of'" (5).

In Culture e Fede 24 Kirkpatrick's article reveals the "problematic aspects of mercy" that Shakespeare's plays explore. Measure for Measure, for example, "faces, without any easy assumption of a conclusion, the problems that arise when human beings attempt to be merciful without a truly reverential sense of Divine Mercy" (2016: 13). However, in The Tempest and the late romances, mercy is presented as "a participation in a complex and responsive action" (17) as it is portrayed, despite its intricacies, "in its fullest sense" (19). Kirkpatrick finds this full vision of mercy articulated in Cardinal Walter Kasper's Mercy: The Essence of the Gospel and the Key to Christian Life (2014). To Kasper, mercy is not just a human virtue but, primarily, "the true name of our Creator" (Kirkpatrick 2016: 17). Similarly, Kirkpatrick perceives in Shakespeare's late plays the force, not of an individual, but of a restorative and also ritual -or even liturgical"transcendent rhythm that displays itself in the works of both nature and grace" (18).

Kasper and Kirkpatrick's perception of mercy as both human compassion and God's forgiveness was central during the Jubilee of Mercy, inaugurated by Pope Francis on 8 December 2015. However, the Vatican's understanding of mercy "unfortunately led to no little dispute and even bitterness and backbiting" (Royal, 2016). For the most conservative wing of the Church the Pope's emphasis on mercy was a "kind of antinomianism: a breakdown of rules and order in favor of freewheeling forgiveness, a weakening of morals and a soft-peddling of ethical demands" (Building a culture, 2016); for the more liberal wing it seemed 'too 'existential,' too focused on the darker currents of our lives - the 'wounds' we suffer from, which need to be healed" (Building a culture, 2016). Amid this controversy, Shakespeare was elevated as an icon of an "unforced, gentle quality of mercy" (Royal, 2016). His representation of mercy in The Merchant of Venice was central to the debates about what true mercy was and Portia's words were appraised "with eyes of Faith" (Taylor, 2015). In the 1964 Shakespeare commemorative performance at the Vatican The Merchant of Venice's trial scene was performed in its entirety and Portia's speech on mercy -a preamble to set up Shylock's punishment- was, therefore, wholly contextualised. The 1964 RSC performance of the trial scene -which Boitani describes as leading to a dead end of contradictions ("un vicolo cieco di contraddizioni" (2018a))-, emphasised, not just Portia's words on mercy, but the play's questioning of Christian mercy, and was mostly welcomed by a Council that vigorously debated the conversion of the Jews, Christian mercy and the Church's responsibility in Nazi persecutions (Cerezo, 2015). However, in 2016, Catholic readings of Portia's lines on mercy did not reveal their contradictory nature and, by taking them out of context, read them just as a reflection on God's compassionate blessings and the bidirectional and reconciliatory nature of mercy. 
Several articles about the intersection between Shakespeare, mercy and the Vatican were published in 2016. On 7 January 2016, Vatican reporter Franca Giansoldati explained that the Globe to Globe staging of Hamlet was blessed by the Holy See for its symbolic nature (21). Reflecting back on the 1964 Shakespeare commemorative event at the Vatican, she pointed to the topicality of Paul VI's closing remarks -addressed to the actors and promoters of the performance- about the playwright's plots as being "a salutary reminder to modern man that God exists, that there is a life after this life, that evildoing is punished and good rewarded" (Paul VI, 1964). ${ }^{3}$ That was still, Giansoldati averred, the 2016 Vatican perception of Shakespeare's plays, including Hamlet. The reporter interpreted the metaphorical nature of Shakespeare's works as a way to avoid the Elizabethan persecution of Catholic views which, to her mind, permeate the playwright's works. Shakespeare's purpose, Giansoldati argued, was to forward the humanistic philosophy which since Thomas Aquinas had marked the Catholic Church's thought by reflecting on issues such as Christian mercy in, for example, the dialogue between Shylock and Antonio in The Merchant of Venice. A few months later, on 23 July 2016, Peter Milward published "La qualitá della misericordia in Shakespeare" in La Civiltà Cattolica. Milward foregrounded the Biblical resonances in Shakespeare's "preaching", especially from the New Testament, where God is shown as a merciful and loving father. Through these plays Shakespeare, affirmed Milward, puts a "homily on mercy" ("una specie di omelia sulla misericordia") on stage which stresses its transformative force, its compatibility with justice and the liberating role of prayer. Before plunging into an analysis of the representation of both mercy and justice by Portia, Isabella, Lear and Prospero, Milward underlined Pope Francis's reference to Shakespeare's description of the "quality of mercy" in The Merchant of Venice shortly after the proclamation of the Year of Mercy.

In 2016 Portia's lines of mercy were also interpreted in light of Pope Francis's exemplary humane acts of mercy during the Jubilee. "In this Holy Year", said the Pope, "we look forward to the experience of opening our hearts to those living on the outermost fringes of society" (2015, April 11: para. 15). The Pope gave "multiple examples of actually reaching out and doing something, person-to-person, for others, whether it's through established Church organizations or individual initiatives" (Royal, 2016). Portia's lines, as Robert Royal explains, were considered a reminder of the need to "re-examine the quality of [our] own practice of mercy" (2016). 


\section{HAMLET AND MERCY}

In a press conference that he shared with Bishop Tighe and Naeem Hayat -one of the two Globe actors playing Hamlet- to present the Globe to Globe Hamlet performance at the Vatican on 13 April 2016, British ambassador Nigel Baker referred to the Pope's own practices of mercy as he described the Globe to Globe tour as "a sort of theatrical expression of Pope Francis reaching out for the peripheries" during the Holy Year (World famous Globe, 2016: 0:48). The Globe to Globe Hamlet (23 April 2014-23 April 2016) travelled to every single country in the world to mark the $450^{\text {th }}$ anniversary of William Shakespeare's birth and performed in a wide array of settings to reach even those in poor and conflictive regions. Like the Pope, who delivered the Catholic message of love and compassion throughout the world, the Globe to Globe Hamlet was perceived at the Vatican as a play whose reflections on revenge had however the capacity to convey ideas about compassion on the seven continents.

Not all responses to the tour were as positive as the Vatican's. The Globe to Globe Hamlet attracted its measure of controversy: the company was attacked for intending to visit North Korea (Park, 2014), and artistic director Dominic Dromgoole's project was accused of cultural imperialism. Dromgoole's lack of interest in the way different cultures have already largely interpreted and translated Shakespeare has been emphasised by Andrew Dickson, for example, who remarks how the director fails to explain how nonAnglophone audiences, many with long-standing traditions of their own of staging Hamlet in translation, engaged with an English-language production, or "what kind of crosscultural conversation the experiment provoked" (2017). In Hamlet: Globe to Globe, Dromgoole defends himself from these accusations and stresses the existence of "crosscultural conversations" during the two-year tour. Hamlet was chosen, he explains, for its elusive, protean and mysterious nature, which allowed it to be received by disparate cultures (2017: 14). Hamlet's elusiveness revealed the performative possibilities of a play that acquired new dimensions at the Vatican, where Hayat described Shakespeare as an author who creates "fundamentally flawed human beings, as we all are ... he does not judge in his writings, he presents the people as they are, with their unique problems" (World famous Globe, 2016: 1:20). Asked by journalist Philippa Hitchen what it meant for him to be performing Hamlet in the Vatican, Hayat expressed how he felt privileged to perform in a venue where they allowed the audience "to do their own work of bringing their own intelligence to the theatre" (Hayat, 2016: 5:35). In that context and at that moment, the actor's words about Shakespeare were surely interpreted in relation to Pope Francis's preaching of the Christian belief in the sinful nature of humankind and his urge "to put mercy before judgment" (Pope Francis, 2015, December 8). To Dromgoole, a global Hamlet performance had the potential to "create a better future out of the ashes of a world that breaks their heart" (2017: 10). The Vatican certainly believed in that potential. 
The Jubilee proclaimed mercy as the principal aspect of a papacy whose episcopal motto is miserando atque eligendo (The coat of arms). This message of mercy was intended to be, like Hamlet, global, universal: the Pope opened the Holy Door of the Bangui Cathedral in the Central African Republic in November 2015 and announced that Doors of Mercy should open in churches all around the world to be able to experience the Holy Year as "an extraordinary moment of grace and spiritual renewal" (Pope Francis, 2015, April 11: para. 3). Bishop Tighe underlined the connection between the staging of Hamlet and the Jubilee of Mercy by stressing this sense of spiritual unity. Hamlet's religious ambiguity allowed Tighe to consider the performance relevant both to "the life of the Church" and "all people" (qted. in Lamb, 2016) -even those who are not explicitly religious - as the lines between religiosity and spirituality, even between secularity and sacredness, blur in the text, signalling what Ken Jackson and Arthur F. Marotti describe as "the strange otherness of Shakespeare's religion" (2011: 9). In an interview with Vatican Radio, Tighe presented Shakespeare's work as essential in the construction of global culture in asking what it means to be human, the purpose of life and the greatness of humankind and its tragedies. The bishop rejected the traditional categorisation of Shakespeare as either "Catholic" or "Protestant" and emphasised Shakespeare's representation of a merciful and not judgmental divinity by significantly concluding that the author's worldview is profoundly shaped by his Christian beliefs, "by a sense of a God who looks over our world, who cares for us" (2016: 7:10).

Despite being a play about revenge and murder most responses to the performance paradoxically also related Hamlet to the religious relevance of mercy; even reports from papers such as La Stampa described Hamlet as "a tragedy which involves the themes of love, betrayal, revenge and mercy" (Lamb, 2016). The audience was given a programme of events with an introduction by Ambassador Baker followed by Cardinal Ravasi's reflections on Shakespeare's plays under the revealing title "Shakespeare between Hate and Mercy". Cardinal Ravasi (2016) reflected on how difficult it is to "define the spiritual face of Shakespeare", who, he sustained, "has left us a textual ocean awash with waves of good and evil, comedy and tragedy, love and hate, splendour and darkness, laughter and tears". Man is sometimes presented as "a work of art", as a "poor player", but also as a creature with "an extraordinary ability to transcend his limits through love". This same duality is found in Shakespeare's depiction of mercy, which has "a sometimes heroic profile, even in its silent manifestations", which the Cardinal found in "the hidden and sober love testimony of Cordelia in King Lear, or the discrete and misunderstood tenderness of Desdemona in Othello". But Shakespeare, Ravasi continued, also "penetrates the poisonous tangle of hateful snakes", which the Cardinal sees in the 
dialogue between Anne and Richard in Richard III in 2.2. However, despite "the strong accent the poet places everywhere on human misery", he concluded, justice and mercy are a powerful presence in his works, most particularly in Portia's lines about them (The Tempest 4.1.190-194), which meaningfully closed the Cardinal's thoughts before the performance.

Baker's introduction to the programme pointed out the singularity of the event -the first time a Shakespeare play was performed in its entirety at the Holy See-, its commemorative nature and the extraordinary task of the Globe to Globe Hamlet taking Shakespeare to people around the world, showing the contemporaneity of the playwright and proving Ben Jonson's First Folio poem right. The ambassador, as Giansoldati, also harked back to Paul VI's closing remarks on the 1964 Shakespeare performance at the Vatican about the playwright's transcendent nature and "profound humanity" leading to "the discovery of the moral laws, which make life great and sacred, and lead us back to a religious understanding of the world. His lofty genius and powerful language induce men to listen with reverence to the great verities he expounds, of death and judgment, of hell and heaven" (Paul VI, 1964). "It therefore", concluded Baker, "seems appropriate that this unique event coincides with the Jubilee of Mercy" (2016, April 13). Baker finally endowed mercy with a metatheatrical nature when he thanked the audience for "joining us on this Vatican Shakespearean adventure" and, prologue-like, asked for their "mercy": "I hope you enjoy the evening. 'For us, and for our tragedy, here stooping to your clemency, we beg your hearing patiently"” (2016, April 13).

Baker's introduction significantly put the emphasis on Claudius's line: "Whereto serves mercy / But to confront the visage of offence?" (3.3.46-47), announcing the prayer scene as the epicentre of the observations about divine mercy in Hamlet. In the play vengeance starts to operate because King Hamlet is murdered in a state of sinfulness, without the sacraments of confession and extreme unction (1.5.77-79). He dies with "all his crimes broad blown, as flush as May" (3.3.81). Hamlet decides not to kill Claudius during the prayer scene as he mistakenly thinks that his uncle is praying and therefore receiving God's mercy and purging his soul (85). He delays his act since he wants to "make justice" and act in retribution by killing his uncle when he is "about some act / That has no relish of salvation in't" (3.3.91-92). Divine mercy must be absent from the scene of the crime. Claudius's soul must be "damned and black / As hell whereto it goes" (94-95). The prayer scene (3.3.35-98) reflects "a new world of divided confessions and consciences" immersed in post-Reformation religious tensions (Cummings, 2019: 202). A renewal of sacramental theology was taking place and the nature of forgiveness was being redefined at a time when penance was abolished as a sacrament. However, as Sara Beckwith points out, "some of the institutions and speech acts connected with it are still an integral part of the economy of salvation" (2011: 35). In the prayer scene, Claudius 
"struggles with a new religion, as he tries (and fails) to find a language of personal penitence through prayer ... The sacrament of penance gives way to an enactment, whether true or false, of personal repentance" (Cummings, 2019: 202).

In 2016, however, the circumstances of King Hamlet's death and Claudius's inner debate acquired a profound Christian sense at the Holy See, away from any seventeenthcentury debate on the redefinition of the sacraments, and pervaded by the theology underlying Pope Francis's following statement in Misericordia et Misera on 20 November 2016: "It is not without significance that the Church mentions mercy explicitly in the formulae of the two 'sacraments of healing', namely, the sacrament of Penance and Reconciliation and the sacrament of the Anointing of the Sick" (para. 5). As Baker states, "the Vatican stage added a new dimension to a production that has travelled from refugee camps to amphitheatres. When Claudius invokes the angels as he prays, trying to repent for his crime, there they were on the walls above his head" (2016, April 14). Claudius's lines, "Then I'll look up. / My fault is past" (3.3.50-51), and his concluding statement in the prayer scene about his words "fly[ing] up" (97) and his "thoughts remain[ing] below" (97) as "[w]ords without thoughts never to heaven go" (98) endowed the wall paintings of the Sala Riaria with new theatrical and religious meaning. ${ }^{4}$ The religious sense of these lines was reinforced in the Globe to Globe Hamlet by the addition of the line "No king on earth is safe if God's his foe" from the Bad Quarto (Dromgoole, 2017: 77). Claudius's sense of guilt prevents him from praying. He cannot be pardoned as he still enjoys the "effects for which [he] did the murder" (3.3.54): "My crown, mine own ambition, and my queen" (55). In a corrupted world, crime can defeat justice, but in Heaven, he admits, we must inevitably face our sins. Claudius acknowledges sin and guilt, invokes divine mercy -the "rain" in "the sweet heavens" (45)-, relies on prayer as a way to prevent the "fall" (49), asks for forgiveness for his past faults (51) and recognises that repentance -despite his inability to attain it- is the only way to be granted divine mercy and forgiveness. At the Vatican Hamlet's prayer scene evoked essential teachings on mercy by Pope Francis, who during the Holy Year stated: "I can and must state that there is no sin that God's mercy cannot reach and wipe away when it finds a repentant heart seeking to be reconciled with the Father" (2016, November 20: para. 12).

Graham Holderness states that after the prayer scene, during his encounter with his mother in 3.4. "Hamlet is not behaving like a Catholic Priest" (2016: 174); he has the Protestant objective of forcing his mother to self-examination and repent for her sins in private prayer to God (174-75). Holderness is responding to a critical tradition that goes back to I. J. Semper's 1946 analysis of Hamlet's encounter with his mother as a scene with Catholic undertones where Hamlet's approach is "entirely spiritual, not unlike that of a 
priest in the confessional" (28). Beckwith calls this scene "Hamlet's Confession" (2011: 55), and Brian Cummings describes it as a "parody of a penitential exercise" (2019: 213). Hamlet asks his mother: "Confess yourself to heaven; / Repent what's past, avoid what is to come" (3.4.140-141). The Prince, says Beckwith, is here "laying title to the role of confessor: his task is to bring Gertrude to shame and contrition, and then to confession" (2011: 55). In the same line, Gerard Kilroy remarks, "[i]t is difficult to avoid the impression that Hamlet is adopting the role of a priest in this scene" (2003: 149). In the Vatican, Hamlet is partly dressed as a priest in some scenes preceding the closet scene. Baker observed how the religious nature of the venue where the play was put on stage added new meanings to a performance during which the Danish prince "even donned a Cardinal's hat for his 'mad' scenes; a standard part of the production, rather than put on for the occasion, I was told!" (2016, April 14). The cardinal's hat was used "as an oblique reference to the Lutheranism of Wittenberg, and was a way for Hamlet to provoke a response from the older generation of Claudius, Gertrude and Polonius, and to lampoon their pomposity" (D. Dromgoole, personal communication, August 24, 2020). In such a Catholic context, however, this dramatic element acquired, as Baker's remark shows, "a new dimension" (2016, April 14). In the context of the Jubilee of Mercy, Gertrude's encounter with the Prince -whom the audience has already seen attired as a lunatic priest in previous scenes- mirrors a failed penitential exercise on the Vatican stage. In the "confession scene" forgiveness is not granted by the "confessor", who is stripped of any moral authority after killing Polonius; mercy is suggested by the Ghost, ${ }^{5}$ who entices Hamlet to treat his mother with kindness, to "step between her and her fighting soul" (3.4.103). Semper, one of the first of a long list of critics that have read the Ghost in Hamlet from a Catholic perspective as a soul coming from Purgatory, describes it in the closet scene as a "compassionate visitant, mindful of the weakness of his wife and perturbed by the emotional instability of his son" (28). However, here we are faced with a perversion of true mercy and a troubling incompatibility (Greenblatt 2013: 237): the Purgatorial Ghost is reformulated as a Senecan revenge spectre. ${ }^{6}$ It has come to "whet [Hamlet's] almost blunted purpose" (3.4.101) and wants mercy for Gertrude partly because her son is losing his focus on the object of revenge. The scene's dismantling of the sacrament of confession -which Pope Francis placed "at the centre once more in such a way that it will enable people to touch the grandeur of God's mercy with their own hands" (2015, April 11: para. 17)- signalled the need for genuine repentance and truthful compassion. The Pope defined confession as "a source of true interior peace" for penitents and confessors, as "a sign of the primacy of mercy always, everywhere, and in every situation, no matter what" (para. 17). However, the comfort offered by this sacrament is absent in the "confession scene" in Hamlet, where the Prince does not heal Gertrude's spirit but makes her look into her soul where she sees "such black and grainèd spots / As will not leave their tinct" (3.4.80-81).

(C) Servicio de Publicaciones. Universidad de Murcia. All rights reserved. IJES, vol. 20(3), 2020, pp. 145-164 Print ISSN: 1578-7044; Online ISSN: 1989-6131 
Hamlet's presentation of the consequences of the absence of mercy appealed to the organisers of the Vatican event. Alluding to the Jubilee of Mercy, Ambassador Baker defined the play as "one of the most powerful examples in literature of what a world without mercy -or with mercy trampled, like Ophelia, underfoot- could look like, the world of Elsinore" (2016, April 14). Bishop Tighe perceived the play's acts and words of retribution as scenes "alert[ing] us to the tragedy, the harm and the damage if a particular concept of justice seems to only find fulfilment in retribution and vengeance" (qted. in Lamb, 2016). The venue, as Baker points out, was transformed by the Globe with "the lightest but most creative of sets" into the Palace of Elsinore (2016, April 14). The inscription Justitia et Pax, which can be read above the Sala Riaria's door behind Hamlet as he calls on heaven to hear his cry of revenge, "brought an extra resonance to his bitter words" (Baker, 2016, April 14). Baker and Tighe are far from critical positions such as Beckwith's (2011), which argues that the tragedies, Hamlet included, are spaces of singularity, not collectivity, in which neither forgiveness nor acknowledgment, both perceived as self-understanding and the knowledge of the other, are possible. The Catholic reading of Hamlet in 2016 was, however, closer to Regina M. Schwartz's (2016) vision of the play as one that, by showing the futility of revenge and violence, opposes retribution and does not exclude the connection between justice and reconciliation -Justitia et Paxas it creates possible spaces of forgiveness. From this perspective, Bishop Tighe's statement that Hamlet "doesn't reject justice but brings us a richer understanding of it" (qted. in Lamb, 2016) is very clarifying. The Vatican organisers of the Hamlet performance saw the play not as a rejection of a kind of justice that implies forgiveness but of the sort of justice that looks for retaliation. Hamlet was, in that sense, also a reflection on mercy.

Schwartz has interpreted Hamlet's widely analysed vacillation as a reflection of "the uncertainty of revenge as a valid moral order" (2016: 104). However, the Prince's following question to Horatio poses a crucial ethical quandary: “is't not perfect conscience / To quit him [Claudius] with this arm? And is't not to be damned / To let this canker of our nature come / In further evil?" (5.2.68-71). As Alan Sinfield states, “[p]olitically, ethically, theologically it can be argued either way" (1980: 94). Certain scenes at the end of the play, which seem to be calling for what John D. Cox perceives as "a charitable response" to the "mystery of suffering" (2007: 78), might be arguing one way by presenting spaces of forgiveness; that is, scenes where compassion, pardon and reconciliation are plausible alternatives to vengeance and punishment and that sustain Ambassador Baker and Bishop Tighe's view of the play. Cox sees, for example, human compassion in Gertrude's description of the death of Ophelia (4.7.138-155), who Kilroy 
envisions as "pass[ing] baptismally through water" (2003: 149), which paradoxically points to the redemptive and cleansing nature of her suicide. The enlargement of the funeral service for Ophelia (5.1.220-228), despite her "doubtful" death (221), shows how human benevolence, coming from a "great command" (222)-allegedly Claudius or Gertrude (George 2010: 61; Cox 2007: 78)-, becomes essential in helping her sinful soul attain divine compassion and remission (Greenblatt, 2013: 246), and serves as a contrast to the priest's unmerciful and "judgmental response" to Ophelia's death (Cox 2007: 78). In the final scene of the play, when Hamlet asks for Laertes's pardon before the duel (5.2.172), reconciliation comes to the fore in the midst of chaos. Seconds before their death, they "exchange forgiveness" (281) and Hamlet refers to heaven's mercy as a way to free Laertes from sin (284). Salvation and eternal rest are briefly introduced at the end of the play by Horatio's response to Hamlet's death, inspired in the Catholic antiphon In Paradisum (5.2.313). These glimpses of mercy in Hamlet support Bishop Tighe's idea that the play evokes "a type of mercy that re-dimensions justice" (qted. in Lamb, 2016), only possible in a reconciled and forgiving world.

Tighe's formulation echoed Pope Francis's perception of justice and mercy as "two dimensions of a single reality" (2015, April 11: para. 20). Pope Francis goes beyond the pardon and judgement bestowed by civil justice and places the forgiveness and salvation that come through divine rule in the centre: "God's justice is his mercy given to everyone as a grace that flows from the death and resurrection of Jesus Christ" (para. 21). In Misericordiae Vultus, the Pope goes back to the Apostle Paul's understanding of divine justice in the Epistle to the Galatians: "We have believed in Christ Jesus, in order to be justified by faith in Christ, and not by works of the law, because by works of the law shall no one be justified' (2:16)" (2015, April 11: para. 20). Hamlin finds Paul's perception of justice, salvation and the sinful nature of humankind reflected in Measure for Measure, as "Isabella urges Angelo to be merciful based on his share in the universal sinfulness of humanity" (2019b: 46), and in The Merchant of Venice (4.1.195-197). These same reflections, Hamlin argues (2019b: 46), are also in Hamlet 2.2. Polonius states that he will use the actors "according to their desert" (2.2.530-531) and Hamlet answers: "Use every man after his desert, and who shall scape whipping?" (532-533). The critic claims that Hamlet's remark to Polonius - "the less they deserve, the more merit is in your bounty" (534-535)- proves that his thoughts are religious rather than just ethical. Milward (2005: 161) and Hassel (1994: 611) explain that what is at stake here is the Lutheran theology of human sin and salvation by grace versus the Catholic doctrine of salvation by merit. However, to Hamlin these lines are "intriguingly hard to categorize as either Protestant or Catholic" (2019b: 46). As Milward asserts, what makes Hamlet such an interesting character is "the strange juxtaposition in his character between Lutheran and Catholic" (2005: 162). The play indulges, as Alison Shell has put it, "in the luxury of theological 
ambivalence" (2010: 113), which, as David Loewenstein and Michael Witmore affirm, "provoke readers and spectators to think about the deepest matters of religious belief and controversy" (2015: 7). ${ }^{7}$ From a Catholic perspective in 2016, however, the exchange between Hamlet and Polonius was deprived of any kind of obscurity. First, it evoked, the common understanding of "justification by God's grace through faith in Christ" (Joint Declaration, 2019: 9) reflected in the Joint Declaration on the Doctrine of Justification, which resolved the theological controversy of the biblical message of salvation during the Reformation and was first conceived as a Catholic-Lutheran agreement in $1999 .{ }^{8}$ Second, it echoed Pope Francis's call to compassion during the Holy Year of Mercy for a sinful, and very often undeserving, human race; a call to follow the pattern of divine mercy, "the bridge that connects God and man, opening our hearts to the hope of being loved forever despite our sinfulness" (2015, April 11: para. 2).

\section{CONCLUSION}

During the Holy Year of Mercy in 2016, Catholic discourses on mercy endowed Shakespeare's reflections on human and divine forgiveness with a quasi-religious authority. Pope Francis's thoughts on compassion, reinforced by Portia's lines on mercy, reflected back on previous ideas by key figures in the Catholic Church - such as Paul VI in 1964 and Saint John Paul II in 1982- that merged Shakespeare, humanity and social reconciliation. Shakespeare was incorporated into a religious discourse intended to present compassion and forgiveness as the cornerstones of Catholic doctrine. During the Jubilee, there were all sorts of Catholic public debates on mercy led by the Vatican -printed volumes, newspaper articles, cycle of lectures- where Shakespeare's dramatic expressions of mercy in plays like Measure for Measure, The Tempest, King Lear and, most especially, The Merchant of Venice were central. Literature and theology joined hands in the attempt to reveal the inner qualities of humankind, the divine essence and the transformative force of mercy.

The main event that connects the Holy Year of Mercy and Shakespeare was the Globe to Globe Hamlet performance at the Vatican on 13 April 2016. The global, and controversial, nature of Dromgoole's production, “tak[ing] Shakespeare's deep humanity to the peripheries" (Baker, 2016, April 14) to celebrate the $450^{\text {th }}$ anniversary of Shakespeare's birth, was welcomed by the Vatican and compared to Pope Francis's 2016 global tour to deliver an ecumenical message of mercy, also questioned by the different wings of the Catholic Church. The mere presence of the Globe actors at the Vatican triggered an enthusiastic response from Ambassador Baker and high officials of the 
Catholic Church such as Cardinal Ravasi or Bishop Tighe, who, irrespective of Shakespeare's faith, praised the author for his capacity to portray a benevolent Christian God, delve into the multifaceted nature of humankind and address spiritual questions about the meaning of existence. What is most striking and interesting is the fact that Hamlet was perceived not just as a play of retaliation but, paradoxical as it may sound, also of mercy. The prayer scene and the closet scene evoked in the Vatican the need of the sacrament of confession and, therefore, repentance to achieve God's mercy and truthful compassion. The play's focus on revenge was read in the Holy See as a warning of the dangers of creating a world without mercy, where justice is only understood in terms of vengeance. The interpretations of Hamlet within the Vatican context were in line with Schwartz's as an anti-revenge play that shows the uselessness of violence and the need to conciliate justice and mercy. Both the scenes where compassion is absent and what I have come to call Hamlet's "glimpses of mercy" sustained the Catholic view of the play as a call for a redefinition of justice as indissolubly linked to God's unconditional mercy.

\section{ACKNOWLEDGEMENTS}

This work was supported by research project PGC2018-095632-B-100, funded by the Spanish Ministry of Science, Innovation and Universities.

My gratitude to the Pontifical Council for Culture, and most specially to Father Benjamin Barba Aguirre, for kindly providing me with the programme of the 2016 Hamlet performance at the Vatican and very relevant material for writing this paper. I would also like to express my thanks to Dominic Dromgoole, Bishop Paul Tighe and Michael Dobson for their invaluable input.

I am also grateful to Paul Franssen and Maria Luisa De Rinaldis for their helpful suggestions.

\section{NOTES}

${ }^{1}$ References to Shakespeare's plays are to the second edition of Stanley Wells and Gary Taylor's William Shakespeare: The Complete Works.

${ }^{2}$ Boitani's lecture on Dante is published as "War of Pity, Angel of Mercy, Eagle of Justice" (2018b) and the ones on Shakespeare as "Shakespeare e la Bibbia: giustizia e misericordia" (2018a). In Il vangelo secondo Shakespeare (2009), later translated as The Gospel According to Shakespeare (2013), Boitani had already reflected on Shakespeare and mercy and had found in King Lear's final encounter with Cordelia the ultimate example of Shakespearean communion between recognition -both of the self and the other- and forgiveness.

${ }^{3}$ On the same day Giansoldati's article was published, L'Osservatore Romano published the Italian translation of Paul VI's 1964 address, originally in English, under the title "Verità sull'inferno e sul cielo" (Paolo VI, 2016). For an analysis of the address see Cerezo, 2015.

${ }^{4}$ The following lines by Hamlet and Horatio would produce the same effect: $1.4 .20 ; 1.5 .92 ; 3.4 .94-$ $95 ; 4.3 .50 ; 5.2 .313$.

${ }^{5}$ Beckwith reminds us that "ghostly father" also means priest or friar (2011: 56).

(C) Servicio de Publicaciones. Universidad de Murcia. All rights reserved. IJES, vol. 20(3), 2020, pp. 145-164 Print ISSN: 1578-7044; Online ISSN: 1989-6131 
${ }^{6}$ For readings of the Ghost as a reflection of theological controversies on spirits during the sixteenth century and for Catholic readings of the Ghost as a soul from Purgatory before 1946 see Semper (1946: 30-40). For a list of authors debating the Ghost's ambiguous nature from 1951 to 1984 see note 46 to chapter five of Greenblatt's Hamlet in Purgatory. See also Cummings (2019). For more recent Catholic approaches to the Ghost see Milward (2005: 163) and Beauregard (2008: 172).

${ }^{7}$ See Kastan (2014: 118) for a review of the landmarks of the critical tradition that envisions Hamlet as a religious play.

${ }^{8}$ It was later joined by the Methodist (2006), Anglican (2016) and Reformed churches (2017).

\section{REFERENCES}

Asquith, C. (2005). Shadowplay. The Hidden Beliefs and Coded Politics of William Shakespeare. New York: Public Affairs.

Baker, C. (2007). Religion in the Age of Shakespeare. Westport: Greenwood.

Baker, N. (2016, April 13). Introduction. Shakespeare at the Vatican, Hamlet by William Shakespeare. Globe to Globe World Tour. Palazzo della Cancelleria, Roma, Programme of the Commemorative Performance.

Baker, N. (2016, April 14). Shakespeare at the Vatican: Family, mercy and a red hat. Retrieved 14 February, 2020 from https://blogs.fco.gov.uk/nigelbaker/2016/04/14/shakespeare-at-thevatican-family-mercy-and-a-red-hat/

Beauregard, D. N. (2018). Catholic Theology in Shakespeare's Plays. Delaware: Delaware Press.

Beckwith, S. (2011). Shakespeare and the Grammar of Forgiveness. Ithaca, NY: Cornell University Press.

Boitani, P. (2009). Il Vangelo secondo Shakespeare. Bologna: Il Mulino.

Boitani, P. (2013). The Gospel According to Shakespeare. (V. Montemaggi \& R. Jacoff, Trans.) Notre Dame: University of Notre Dame Press.

Boitani, P. (2018a). Shakespeare e la Bibbia: giustizia e misericordia. In E. Di Rocco \& E. Spandri (Eds.), Mondi di fede e di invenzione: Intersezioni tra religione e letteratura [E-reader version]. Rome: Studium.

Boitani, P. (2018b). War of pity, angel of mercy, eagle of justice. Studium, 114(3), 393-402.

Building a culture of mercy. (2016, December 2). Global Catholic Climate Movement. Retrieved 14 February, 2020 from https://catholicclimatemovement.global/building-a-culture-of$\underline{\text { mercyl }}$

Cerezo, M. (2015). Shakespeare at the Vatican, 1964. In C. Calvo \& Coppélia Kahn (Eds.), Celebrating Shakespeare. Commemoration and Cultural Memory (pp. 121-139). Cambridge: Cambridge University Press.

Cox, J. D. (2007). Seeming Knowledge. Shakespeare and Skeptical Faith. Waco, TX: Baylor University Press.

(C) Servicio de Publicaciones. Universidad de Murcia. All rights reserved. IJES, vol. 20(3), 2020, pp. 145-164 Print ISSN: 1578-7044; Online ISSN: 1989-6131 
Cummings, B. (2019). Remembering the dead in Hamlet. In H. Hamlin (Ed.), The Cambridge Companion to Shakespeare and Religion [E-reader version] (pp. 200-217). Cambridge: Cambridge University Press.

Dickson, A. (2017, April 14). Hamlet, Globe to Globe by Dominic Dromgoole review neocolonial folly? The Guardian. Retrieved 14 February, 2020 from https://www.theguardian.com/books/2017/apr/14/hamlet-globe-to-globe-dominicdromgoole-review-shakespeare

Dromgoole, D. (2017). Hamlet: Globe to Globe: 193,000 Miles, 197 Countries, One Play [Ereader version]. Edinburgh: Canongate Books.

George, D. (2010). Abbreviated rites and incomplete ceremonies: Dramatic necessity, official prohibition, or cultural inspiration? In B. Batson (Ed.), Word and Rite: The Bible and Ceremony in Selected Shakespearean Works (pp. 45-64). Cambridge: Cambridge Scholars Publishing.

Giansoldati, F. (2016, January 7). Shakespeare il Vaticano 'benedice' l’Amleto. Il Messaggero, 21. Greenblatt, S. (2013). Hamlet in Purgatory. Princeton: Princeton University Press.

Hamlin, H. (2013). The Bible in Shakespeare. Oxford: Oxford University Press.

Hamlin, H. (2019a). Preface. In H. Hannibal (Ed.), The Cambridge Companion to Shakespeare and Religion [E-reader version] (pp. xi-xiv). Cambridge: Cambridge University Press.

Hamlin, H. (2019b). The Renaissance Bible. In H. Hannibal (Ed.), The Cambridge Companion to Shakespeare and Religion [E-reader version] (pp. 34-50). Cambridge: Cambridge University Press.

Hassel, R. C. (1994, Autumn). Hamlet's 'Too, Too Solid Flesh'. The Sixteenth Century Journal, 25(3), 609-622.

Hayat, N. (2016, April 13). Hamlet in the Vatican at the end of two-year world tour. Interview with Philippa Hitchen. Vatican Radio. Retrieved 20 August, 2020 from http://www.archivioradiovaticana.va/storico/2016/04/13/hamlet_in_the_vatican_at_the_end of two year world tour/en-1222580

Holderness, G. (2016). The Faith of Shakespeare. Oxford: Lion.

Holland, P. (Ed.). (2001). Shakespeare and Religions. Shakespeare Survey, 54.

Jackson, K., \& A. F. Marotti. (2004, Winter). The turn to religion in Early Modern English Studies. Criticism, 46(1), 167-190.

Jackson, K., \& A. F. Marotti. (2011). Shakespeare and Religion. Early Modern and Postmodern Perspectives. Notre Dame: University of Notre Dame Press.

John Paul II. (1982, May 30). Holy Mass of Pentecost. Homily of John Paul II. Retrieved 14 February, 2020 from http://w2.vatican.va/content/john-paulii/en/homilies/1982/documents/hf_jp-ii_hom_19820530_coventry.html

Joint Declaration on the Doctrine of Justification by the Lutheran World Federation and the Catholic Church. (2019). 20 $0^{\text {th }}$ Anniversary Edition. Geneva: The Lutheran World Federation. $\begin{array}{llll}\text { Retrieved } & 1 & \text { December, } & 2020\end{array}$ https://www.lutheranworld.org/sites/default/files/2019/documents/190603joint declaration on the doctrine of justification 20 anniversary edition-en.pdf.pdf

Kasper, W. (2014). Mercy: The Essence of the Gospel and the Key to Christian Life. New Jersey: Paulist Press. 
Kastan, D. S. (2014). A Will to Believe. Shakespeare and Religion. Oxford: Oxford University Press.

Kilroy, G. (2003). Requiem for a prince: Rites of memory in Hamlet. In R. Dutton, A. Findlay \& R. Wilson (Eds.), Theatre and Religion. Lancastrian Shakespeare (pp. 143-160). Manchester: Manchester University Press.

Kirkpatrick, R. (2016). Shakespeare in the light of Cardinal Kasper's mercy. Culture e Fede, 24(1), 13-19.

Lamb, C. (2016, April 13). Shakespeare tragedy comes to the Holy See. La Stampa. Retrieved 14 February, 2020 from www.lastampa.it/2016/04/13/vaticaninsider/eng/thevatican/shakespeare-tragedy-comes-to-the-holy-see-

LkVQkvKSUhmgIiiWAsIyBN/pagina.html

Loewenstein D. \& M. Witmore (Eds.). (2015). Shakespeare and Early Modern Religion. Cambridge: Cambridge University Press.

Loewenstein D. \& M. Witmore. (2015). Introduction. In D. Loewenstein \& M. Witmore (Eds.), Shakespeare and Early Modern Religion (pp. 1-19). Cambridge: Cambridge University Press.

Lupton, J. R. (2005). Citizen-Saints. Shakespeare and Political Theology. Chicago/London: The University of Chicago Press.

Marx, S. (2000). Shakespeare and the Bible. Oxford: Oxford University Press.

Mayer, J. (2006). Shakespeare's Hybrid Faith. New York: Palgrave McMillan.

Milward, P. (2005). Shakespeare the Papist. Naples, Fla: Sapientia.

Milward, P. (2016, July 23). La qualitá della misericordia in Shakespeare. La Civiltà Cattolica.

$\begin{array}{lllll}\text { Retrieved } & 14 & \text { February, } & 2020 & \text { from }\end{array}$ http://www.notedipastoralegiovanile.it/index.php?option=com_content\&view=article \&id=1 1352:la-qualita-della-misericordia-in-shakespeare\&catid=173\&Itemid $=101$

Park, M. (2014, March 12). Globe Theatre defends its world tour including North Korea. CNN $\begin{array}{lllll}\text { World. } & \text { Retrieved } & 14 & \text { February, } & 2020\end{array}$ https://edition.cnn.com/2014/03/12/world/asia/hamlet-north-korea/

Paolo VI. (2016, January 7). Verità sull'inferno e sul cielo. L'Osservatore Romano, 4.

Paul VI. (1964, November 12). Address of Paul VI for the fourth centenary of the Birth of William Shakespeare. Retrieved 14 February, 2020 from http://www.vatican.va/content/paulvi/en/speeches/1964/documents/hf_p-vi_spe_19641112_shakespeare.html

Pegoraro, P. (2016). Bibbia, teologia e letteratura un'alleanza feconda. La Gregoriana, XXI.50, $22-$ $\begin{array}{lllll}\text { 25. Retrieved } & 14 & \text { February, } & 2020 & \text { from }\end{array}$ https://issuu.com/unigregoriana/docs/ lagregoriana50 web

Pope Francis. (2015, April 11). Misericordiae Vultus. Bull of Indiction of the Extraordinary Jubilee $\begin{array}{llllll}\text { of } & \text { Mercy. } & \text { Retrieved } & 14 & \text { February, } & 2020\end{array}$ w2.vatican.va/content/francesco/en/bulls/documents/papafrancesco_bolla_20150411_misericordiae-vultus.html 
Pope Francis. (2015, December 8). Homily of his Holiness Pope Francis. Retrieved 20 August, 2020 from http://www.vatican.va/content/francesco/en/homilies/2015/documents/papafrancesco_20151208_giubileo-omelia-apertura.html

Pope Francis. (2016, January 24). Communication and mercy: A fruitful encounter. Retrieved 14 February, 2020 from w2.vatican.va/content/francesco/en/messages/communications/documents/papafrancesco_20160124_messaggio-comunicazioni-sociali.html

Pope Francis. (2016, November 20). Misericordia et Misera. Retrieved 14 February, 2020 from http://w2.vatican.va/content/francesco/en/apost_letters/documents/papa-francesco-letteraap_20161120_misericordia-et-misera.html

Ravasi, G. (2016, April 13). Shakespeare between hate and mercy. In Shakespeare at the Vatican. Hamlet by William Shakespeare. Globe to Globe World Tour. Palazzo della Cancelleria, Roma. Programme of the Commemorative Performance.

Rouse, R. (2016). Editorial. Culture e Fede, 24(1), 5.

Royal, R. (2016, December 5). The quality of mercy. The Catholic Thing. Retrieved 14 February, 2020 from www.thecatholicthing.org/2016/12/05/the-quality-of-mercy/

Schwartz, R. M. (2016). Loving Justice, Living Shakespeare. Oxford: Oxford University Press.

Semper, I. J. (1946). Hamlet without Tears. Iowa: Dubuque.

Shell, A. (2010). Shakespeare and Religion. London: Bloomsbury.

Shuger, D. K. (2001). Political Theologies in Shakespeare's England. New York: Palgrave.

Sinfield, A. (1980). Hamlet's special providence. Shakespeare Survey, 33, 89-97.

Taylor, B. A. (2015, December 5). Shakespeare on 'The Quality of Mercy'. Catholic365.Com. Retrieved 14 February, 2020 from www.catholic365.com/article/3007/shakespeare-on-thequality-of-mercy.html

Taylor, D. \& D. N. Beauregard. (2003). Shakespeare and the Culture of Christianity in Early Modern England. New York: Fordham University Press.

The coat of arms of Pope Francis. Retrieved 14 February, 2020 from http://w2.vatican.va/content/francesco/en/elezione/stemma-papa-francesco.html

Tighe, P. (2016, April 11). Shakespeare's Hamlet coming to Vatican. Interview with Vatican Radio www.archivioradiovaticana.va/storico/2016/04/11/shakespeares hamlet coming to the vat ican/en-1221805

Wells, S. \& G. Taylor. (2005). William Shakespeare: The Complete Works. Oxford: Clarendon Press.

Williams, R. (2019). Finding the remedy. In H. Hamlin (Ed.), The Cambridge Companion to Shakespeare and Religion [E-reader version] (pp. 285-290). Cambridge: Cambridge University Press.

Wilson, R. (2004). Secret Shakespeare. Manchester: Manchester University Press.

Wong, J. (2018). The Translatability of the Religious Dimension in Shakespeare. Eugene: Pickwick Publications.

World famous Globe Theatre group performs Shakespeare's Hamlet at the Vatican. (2016, April 21). Rome Reports.Com. YouTube. Retrieved 14 February, 2020 from www.youtube.com/watch?v=18tlBH2yE-0 